\title{
Retention factors in relation to organisational commitment in medical and information technology services
}

\author{
Authors: \\ Jeannette van Dyk ${ }^{1}$ \\ Melinde Coetzee ${ }^{1}$ \\ Affiliation: \\ ${ }^{1}$ Department of Industrial \\ and Organisational \\ Psychology, University of \\ South Africa, South Africa

\section{Correspondence to:} \\ Melinde Coetzee \\ Email: \\ coetzm1@unisa.ac.za

\section{Postal address} \\ PO Box 392, University of \\ South Africa 0003, \\ South Africa

\section{Dates:} \\ Received: 17 Oct. 2011 \\ Accepted: 19 Mar. 2012 \\ Published: 18 July 2012 \\ How to cite this article: \\ Van Dyk, J., \& Coetzee, \\ M. (2012). Retention \\ factors in relation to \\ organisational commitment \\ in medical and information \\ technology services. SA \\ Journal of Human Resource \\ Management/SA Tydskrif vir \\ Menslikehulpbronbestuur, \\ 10(2), Art. \#433, 11 pages. \\ http://dx.doi.org/10.4102/ \\ sajhrm.v10i2.433
}

Orientation: Retaining staff with scarce and critical skills in the medical and information technology (IT) industry has become a top priority because of skills shortages.

Research purpose: The objectives of the study were to investigate empirically: (1) the relationship between employees' satisfaction with organisational retention factors (measured by the Retention Factors Scale) and their organisational commitment (measured by the Organisational Commitment Questionnaire) and (2) whether gender, age, race and tenure groups differ significantly in terms of these variables.

Motivation for the study: Medical and information technology professionals have specialised and hard to replace skills. They also have strong tendencies to leave their organisations and countries. Understanding the retention factors that will increase their organisational commitment may benefit the organisations who want to retain their valuable talent.

Research design, approach and method: The researchers used a cross-sectional survey design to collect data from a purposive sample of 206 staff members who had scarce skills in a South African medical and information technology services company. Correlational and inferential statistics were computed to achieve the objectives.

Main findings: The results showed that the participants' satisfaction with retention factors has a significant relationship with their organisational commitment and that the biographical groups differ significantly in terms of the variables.

Practical/managerial implications: The measured retention factors were all associated with human resource management practices that influence employees' intentions to leave.

Contribution/value-add: The results are important to managers who are interested in retaining staff who have scarce skills and provide valuable pointers for designing effective retention strategies.

\section{Introduction}

\section{Key focus of the study}

Retaining staff with scarce and critical skills in the medical and information technology (IT) industries has become a top priority for contemporary South African organisations (Van Dyk, 2011). The study aims to investigate the relationship between staff satisfaction with retention factors in relation to their organisational commitment in a South African medical and information technology services company.

\section{Background to the study}

Research has shown that medical (Hill, 2011; Holtom \& O'Neill, 2004) and IT professionals have strong tendencies to leave their organisations (Korunka, Hoonakker \& Carayon, 2008) and countries (Bezuidenhout, Joubert, Hiemstra \& Struwig, 2009; Rasool \& Botha, 2011; Statistics South Africa, 2005). Medical (Holtom \& O’Neill, 2004) and IT professionals have specialised and hard to replace skills (McKnight, Philips \& Hardgrave, 2009).

Although it may be costly to replace and train new employees in these industries, turnover increases the workload of, and demands on, existing staff members. This causes overwork and burnout, which could result in greater turnover (Stroth, 2010). In addition, there seems to be consensus that skills shortages are major obstacles to economic growth and job creation in South Africa (Bhorat, Meyer \& Mlatsheni, 2002; Kraak, 2008; Rasool \& Botha, 2011).

In the search for solutions to overcome the problem of skills shortages in South African workplaces, it seemed beneficial to gain insight into the relationship between employees' satisfaction with 
organisational retention factors and their organisational commitment as well as how employees from different gender, age, race and tenure groups vary in terms of these variables. This knowledge could influence the design of more effective retention strategies for staff with scarce and critical skills in South Africa's multicultural organisational context.

\section{Trends from the research literature}

Organisational commitment has been the subject of extensive research into retention (Neininger, Lehmann-Willenbrock, Kauffeld \& Henschel, 2010). However, there seems to be little research into the organisational commitment of staff with scarce skills in the South African medical and IT services environment (Van Dyk, 2011). Lack of commitment to their organisations may cause employees to seekalternative positions (Reed, Kratchman \& Strawser, 1994). Despite challenges by some researchers that organisational commitment is less relevant in the contemporary workplace (Savickas et al., 2009), recent research has shown that the affective commitment, or psychological attachment, of employees remains important for business leaders if they are to attract, motivate and retain key talent (Morrow, 2011).

Organisational commitment results in positive attitudes to jobs and affects outcomes like employees' intentions to leave, organisational citizenship behaviour, performance and job satisfaction (Neininger et al., 2010). Corporate and employee-centred human resource practices like work-life balance, compensation, supervisor support, communication, rewards and recognition, training and development, job characteristics and opportunities to develop careers influence the commitment of employees (Döckel, 2003; Joāo, 2010; Lumley, 2009). Therefore, these practices have become important factors for retaining staff (Döckel, 2003).

\section{Literature review}

\section{Retention factors}

For the purpose of this study, retention factors are the factors that facilitate the retention or departure of employees and their decisions to leave or remain, depending on their priorities (Netswera, Rankhumise \& Mavundla, 2005). A South African study that Döckel (2003) conducted uncovered six critical retention factors that organisations need to consider if they are to retain employees with high technology skills. These factors are relevant to the present study and include:

- compensation

- job characteristics

- opportunities for training and development

- supervisor support

- career opportunities

- work-life balance.

Each of these factors is discussed below.

Compensation includes monetary and non-monetary rewards in return for the work employees do.
Monetary rewards include basic salaries, incentives and stock options. Non-monetary rewards are indirect financial rewards employees receive for their labour (Döckel, 2003). Salary and financial incentives are direct and indirect precursors of intentions to leave (Luna-Arocas \& Camps, 2008).

Job characteristics include skill variety and job autonomy because highly specialised knowledge workers prefer jobs in which they can use a variety of skills, present challenging assignments and offer job autonomy (Spector, 2008). Knowledge workers are employees who have critical knowledge about core products and services (Coetzee \& Roythorne-Jacobs, 2007).

Training and development, as well as educational investments, aim to offer opportunities for advancement. Employees might perceive that their organisations value them. This gives employees a sense of self-worth and increases their affective commitment (Döckel, 2003; Meyer \& Allen, 1997).

According to Kraimer, Seibert, Wayne, Liden and Bravo (2011), opportunities for training and development support employee growth and development. Research by Joāo (2010) has shown that training and development are important factors for retaining professionally qualified employees. Training and development programmes could send important messages to employees that their organisations are investing in them and that their organisations regard them as valuable resources (Kraimer et al., 2011). On the other hand, Maurer and Lippstreu (2008) found that employees with low levels of learning orientation do not respond to development support with greater commitment.

Supervisor support includes the recognition and feedback that supervisors give to employees. Various studies show the importance of recognition and feedback for retaining valuable employees (Allen, Shore \& Griffeth, 2003; Morrow, 2011). Perceived organisational support increases the affective commitment of employees in the long term (Morrow, 2011).

Career opportunities include the internal and external career options that employees have. Internal career opportunities could lie in the employees' current organisations, like promotions or moves to different positions. External career opportunities could mean moving to other organisations (Joāo, 2010).

Research has shown that career growth is important for increasing employees' affective commitment to their organisations and for reducing their intentions to leave (Joāo, 2010; Morrow, 2011; Neininger et al., 2010; Weng, McElroy, Morrow \& Liu, 2010). Kraimer et al. (2011) found that perceived career opportunities significantly predict job performance and turnover. When employees perceive that there are many career opportunities in their organisations, it could result in better job performance and reduce their intentions to leave. Joāo (2010) also found that the need 
for career growth and opportunities for advancement, as well as challenging work, are significant factors that stop professionally qualified employees from leaving their organisations.

Parkes and Langford (2008) describe work-life balance as the ability of employees to meet their work and family commitments as well as other non-work responsibilities and activities. Döckel (2003) argues that organisations need to accommodate employees by providing access to telecommuting, childcare centres, referral programmes and employee assistance programmes. Employees regard worklife balance policies as organisational care and positively influence employees' psychological attachment to their organisations (Döckel, 2003).

The gender distribution in organisations also influences mobility. Women who work in male-dominated occupations have more difficulty moving up the hierarchy, presumably because of gender bias (Maume, 1999). Women may have fewer opportunities for job development and mentoring in male-dominated occupations (Lai, Lin \& Leung, 1998; Ohlott, Ruderman \& McCauley, 1994) and could be less committed to their organisations (Martins \& Coetzee, 2007).

Govaerts, Kyndt, Dochy and Baert (2011) found a positive relationship between age, retention and intentions to stay and a negative relationship between age, retention and intentions to leave. The findings show that younger employees are significantly more likely to leave their organisations than older employees are. Older employees have more difficulty finding new jobs, because they suffer from negative stereotyping and age discrimination (Posthuma \& Campion, 2009), than younger ones do. Ng and Feldman (2009) argue that the relationship between age and turnover might have changed over the last 20 years because of changes in work environments and norms for job mobility.

\section{Organisational commitment}

Meyer and Allen's (1991) conceptualisation of organisational commitment is relevant to the present study. Their multidimensional approach integrates attitudinal and behavioural approaches to commitment in order to create three distinct dimensions of organisational commitment: affective, continuance and normative commitment.

Affective commitment refers to employees' commitment through emotional bonds, links to, and engagement in, their organisations. Continuance commitment refers to employees' perceptions of the benefits and advantages they could lose if they leave their organisations. Normative commitment refers to employees' sense of indebtedness to their organisations. Employees may feel obliged to stay in their organisations because of social norms (Meyer \& Allen, 1991). Affective and normative commitments reflect employees' attitudinal dispositions whereas continuance commitment shows their behavioural orientations (Meyer \& Allen, 1997).
One generally assumes that organisational commitment reduces abandonment behaviours that include tardiness and leaving. In addition, employees, who are committed to their organisations, could be more willing to participate in 'extra-role' activities, like being creative or innovative. These frequently guarantee organisations' competitiveness in the market (Katz \& Kahn, 1978). Research by Martin (2008) shows that affective commitment influences normative commitment positively and normative and affective commitment influences continuance commitment.

Affective commitment has a stronger effect than normative commitment does on the intention of employees to continue working in their organisations. Affective commitment creates emotional bonds that can cause employees to develop a sense of responsibility and duty (normative commitment) to their organisations. On the other hand, employees cannot behave as they want to because they feel an obligation to their organisations although they are unhappy in them. In addition, normative commitment can also lead to continuance commitment because employees' emotional involvement in their organisations may lead to a desire to continue (Martin, 2008).

According to Meyer and Allen (1991), employees, whose experiences meet their expectations and if their organisations satisfy their basic needs, tend to develop stronger affective attachments to their organisations than do those employees whose experiences are less satisfying.

In addition, continuance commitment may develop as employees recognise that they have accumulated investments (Becker, 1960) that they could lose if they leave their organisations or if there are limited alternative employment prospects. Furthermore, normative commitment develops because of socialisation experiences that emphasise the importance of remaining loyal to their employers (Morrow, 2011) or through organisational benefits (like car allowances, medical aids or study leave). Research that Manetje and Martins (2009) conducted suggests that employees, who are affectively committed to their organisations, are more willing to maintain their relationships with their organisations than are those who are normatively and continuance committed.

Research by Coetzee, Schreuder and Tladinyane (2007) showed no significant differences between the organisational commitment of Blacks and Whites and between men and women. Metcalfe and Dick (2002) reported similar findings about the organisational commitment of men and women.

With regard to age, Bentein, Vandenberghe, Vandenberg and Stinglhamber (2005) found evidence for a linearly declining change in affective commitment and normative commitment over time. Research by Meyer and Allen (1984) showed that older workers become more attitudinally committed to organisations than younger ones do. Ferreira and Coetzee (2010) also found that older employees are more affectively and normatively committed to their organisations than their younger counterparts are. 


\section{Research objectives}

The objectives of the study were to investigate empirically:

- the relationship between employees' satisfaction with organisational retention factors and their organisational commitment

- whether gender, age, race and tenure groups differ significantly in terms of these variables.

\section{The potential value of the study}

This study contributes to the existing body of theory on staff retention and the organisational commitment of employees in South African multicultural organisations.

The literature showed significant relationships between organisational retention factors and employees' intentions to stay with, or leave, their organisations as well as their levels of organisational commitment. However, researchers have not investigated the relationship between these variables in the South African medical and information technology working environments.

In addition, research on the differences between the biographical groups in terms of these variables is limited in the South African workplace.

Furthermore, because of South Africa's diverse multicultural workforce, organisations need to consider possible differences between the levels of satisfaction that employees have with their organisations' retention factors and their employees' levels of commitment when they adopt talent retention strategies.

\section{Research design \\ Research approach}

The researchers used a cross-sectional survey design (Shaughnessy, Zechmeister \& Zechmeister, 2003) to achieve their research objectives. They collected their data at one point in time in a South African medical and information technology services company. They used a correlational approach.

\section{Research method}

\section{Research participants}

The sampling method the researchers used depended on which skills the senior managers in the human resources division of the company identified as scarce and whether the participants were willing and available to participate in the study. The researchers drew an initial purposive sample $(N=843)$ from the population of 2170 professional and management level staff in the company and invited them to participate in the study. The participants who voluntarily participated in the study yielded a response rate of $24.44 \%$ $(N=206)$.

The sample was skewed towards women (73\%) between the ages of 30 and $39(40 \%)$ and between 40 and 49 (30\%). Most of the participants were married (59\%) or single, divorced or widowed $(41 \%)$. With regard to race groups, $53 \%$ were Whites and $47 \%$ were Blacks. Africans comprised 13\%, Coloureds $22 \%$ and Asian $12 \%$ of the latter group. Most of the participants had post-school qualifications (77\%). Most had certificates $(12 \%)$, diplomas $(34 \%)$, degrees $(18 \%)$ or postgraduate qualifications $(13 \%)$. With regard to tenure, most participants had worked in the company for fewer than five years (45\%), 23\% had worked for between six and 10 years whilst $21 \%$ had worked for between 11 and 15 years. Only $11 \%$ had been in their current positions for 15 years or more. The participants' length of employment in their current positions was mainly between three and five years $(31 \%)$, between one and two years (25\%), less than a year $(21 \%)$, between 6 and 10 years (17\%) and more than 11 years (6\%). Most participants worked at a professional level (69\%), whilst $15 \%$ worked at management level and $17 \%$ at senior management level.

\section{Measuring instruments}

The well-established Organisational Commitment Questionnaire (OCQ) (Meyer \& Allen, 1997) was used to measure organisational commitment. The OCQ is a multi-factor measure for assessing employees' affective commitment (eight items), continuance commitment (seven items) and normative commitment (seven items) on a six-point Likert-type scale.

With regard to internal consistency reliability, Meyer, Allen and Smith (1993) reported the following Cronbach's Alpha coefficients: affective commitment (.82), continuance commitment (.74) and normative commitment (.83). The median reliabilities for the affective, continuance and normative scales were $.85, .79$ and .73 respectively. With few exceptions, the reliability estimates exceed .70 (Meyer \& Allen, 1997). The researchers also obtained acceptable (high) internal consistency reliabilities in the present study: affective commitment (.90), continuance commitment (.84) and normative commitment (.70).

Döckel (2003) developed the Retention Factor Scale (RFS). The researchers used it (with a six-point Likert-type scale) to measure the participants' satisfaction with seven retention factors:

- compensation (13 items)

- job characteristics (four items)

- opportunities for training and development (six items)

- supervisor support (six items)

- career opportunities (six items)

- work-life balance (four items)

- commitment to the organisation (three items).

A factor analysis on the RFS that Döckel (2003) conducted confirmed the construct validity of the questionnaires. With regard to internal consistency reliability, Döckel, Basson and Coetzee (2006) reported the following Cronbach's Alpha coefficients: compensation (.90), job characteristics (.41), opportunities for training and development (.83), supervisor support (.90), career opportunities (.76), work-life balance (.87) and commitment to the organisation (.89). 
The researchers also obtained acceptable (medium to high) internal consistency reliabilities for the present study: compensation (.95), job characteristics (.67), opportunities for training and development (.88), supervisor support (.83), career opportunities (.73), work-life balance (.88) and commitment to the organisation (.89).

\section{Research procedure}

With regard to ethics, the researchers obtained clearance to conduct the research from the participating organisation.

The researchers asked the selected employees to participate voluntarily in the research by completing the questionnaires. They sent the questionnaires to participants via the company's internal mail system. A covering letter, which explained the purpose of the study and emphasised the confidentiality of the research project, accompanied the questionnaires. The letter also explained that the researchers would use all information for research purposes only. The participants gave their informed consent to participate in the study.

The participants completed the questionnaires anonymously. The participants returned completed questionnaires to the researchers via the external mail system. The researchers were available for any questions and concerns and kept the completed questionnaires secure. They captured the raw data and converted them to an SPSS dataset.

\section{Statistical analysis}

The Statistical Programme for Social Sciences (SPSS, version 17,2008 ) was used to analyse the data. Descriptive statistics, correlational and inferential statistics were calculated.

Cronbach's Alpha coefficients were used to assess the internal consistency of the measuring instruments. Field (2005) lists four assumptions that one needs to meet for using parametric statistics: normality, homogeneity of variance, interval data and independence. The researchers considered these assumptions before deciding to use parametric statistics.

The results of the Kolmogorov-Smirov and ShapiroWilk tests for the OCQ and RFS were not significant $(p>.05)$. Therefore, the researchers concluded that the participants were normally distributed. The Levene's test for equal variances showed that all the variables showed homogeneity of variance. The assumptions of interval data and independence require an assessment by the researchers. The researchers concluded that the study met the assumptions adequately and computed parametric statistics.

Pearson product-moment correlations were calculated to determine the direction and strength of the relationships between the variables. In order to counter the probability of a type 1 error, the significance value was set at the $95 \%$ confidence level $(p \leq .05)$. For the purposes of this study, $r$-values $\geq$ than .30 (medium effect) (Cohen, 1992) were treated as practically significant.
Standard multiple regression analyses were performed to identify the RFS variables that predicted or provided the best explanation for the portion of the total variance in the scores of the dependent variables (the OCS variables). A number of independent (RFS) variables had to be considered. Therefore, the value of the adjusted $R^{2}$ was used to interpret the results. The $F$-test was used to test whether there was a significant regression between the independent and the dependent variables. For the purposes of this study, $R^{2}$ values that were larger than .13 (medium effect) were treated as practically significant (Cohen, 1992).

The $t$-tests were used to compute the mean differences between the gender groups. Analyses of variance (ANOVAs) were performed to test for significant mean differences between the various age, race and tenure groups. Cohen's $d$ and partial Eta squared values were computed to assess the magnitude of the differences between the biographical groups.

\section{Results \\ Descriptive statistics}

Table 1 gives the means, standard deviations, internal consistency reliability coefficients and inter-correlations for the RFS and OCS variables. The results show that the participants felt moderately committed to the organisation. The participants felt moderately satisfied with their job characteristics $(\mathrm{M}=4.53$; $\mathrm{SD}=1.06)$; commitment to the organisation $(\mathrm{M}=4.38 ; \mathrm{SD}=1.43)$; and supervisor support $(\mathrm{M}=4.23 ; \mathrm{SD}=1.17)$. Table 1 shows that the participants felt slightly satisfied with their work-life balance $(\mathrm{M}=$ 3.95; $\mathrm{SD}=1.41)$; career opportunities $(\mathrm{M}=3.59$; $\mathrm{SD}=1.00)$; compensation $(\mathrm{M}=3.53 ; \mathrm{SD}=1.18)$; compensation $(\mathrm{M}=3.53$; $\mathrm{SD}=1.18)$; and opportunities for training and development $(\mathrm{M}=3.47 ; \mathrm{SD}=1.30)$.

\section{Correlation statistics}

Table 1 shows that, with the exception of work-life balance, the affective and continuance commitment variables correlated positively and significantly with the RFS variables. Normative commitment correlated positively and significantly only with the compensation $(r=.24$; $p \leq .001$; small practical effect), career opportunities $(r=.13$; $p \leq .05$; small practical effect) and commitment to organisation ( $r=.34 ; p \leq .001$; medium practical effect) RFS variables. Not surprisingly, Table 1 shows that affective commitment $(r=.59$; $p \leq .001$; large practical effect) and continuance commitment $(r=.61 ; p \leq .001$; large practical effect) had significantly higher correlations with the commitment to organisation variable than with the other RFS variables. Continuance commitment had significantly lower correlations with the job characteristics $(r=.19 ; p \leq .05$; small practical effect) and supervisor support $(r=.22 ; p \leq .001$; small practical effect) variables.

\section{Multiple regression statistics}

Table 2 presents the significant results. In terms of multicollinearity, the current study yielded tolerance values 
close to 1.0 (between $\geq .71$ an $\leq .89$ ) and VIF values of $\leq 1.41$. They are lower than the cut-off of $\geq 2.5$ to $\geq 4.0$ suggested for small samples. Therefore, the researchers concluded that multicollinearity was not a particular concern in the context of the current study, suggesting that they could interpret the Beta $(\beta)$ values with more confidence (Field, 2005).

Table 2 shows that the regression models explained large $\left(R^{2}=40 \%-41 \%\right)$ practical effect percentages of variance in the affective commitment and continuance commitment dependent variables and small $\left(R^{2}=12 \%\right)$ practical effect percentages of variance in the normative commitment variable at $F(p) \leq .001$.

Table 2 shows that the RFS commitment to organisation variable contributed significantly and positively to the variance in the affective commitment $(\beta=.43 ; p \leq .001)$, normative commitment $(\beta=.40 ; p \leq .001)$ and continuance commitment $(\beta=.50 ; p \leq .001)$ variables. The career opportunities variable contributed significantly and positively to the variance in the affective commitment $(\beta=$ $.20 ; p \leq .001)$ and continuance commitment $(\beta=.23 ; p \leq .001)$ variables. Job characteristics $(\beta=.17 ; p \leq .01)$ contributed significantly and positively to the variance in the affective commitment variable whilst the supervisor support $(\beta=-.16$; $p \leq .05$ ) variable contributed significantly and negatively to the variance in the normative commitment variable.

\section{Significant mean differences: Gender}

Table 3 gives the results of the independent samples $t$-test. They provide some support that men and women differ significantly in their levels of satisfaction with retention factors and their organisational commitment. However, although Table 3 shows that the men participants scored significantly higher than their women counterparts on affective commitment $(\mathrm{M}=4.18$ vs. $\mathrm{M}=3.90)$ and satisfaction with career opportunities ( $\mathrm{M}=3.91$ vs. $\mathrm{M}=3.91)$, the size of these differences is small $\left(d \leq .39 ; \eta^{2} \leq 39 \%\right)$. The researchers observed no significant mean differences for the other RFS and OCQ variables.

TABLE 1: Means, standard deviations, internal consistency reliability values and intercorrelations for retention factors and organisational commitment $(N=206)$.

\begin{tabular}{|c|c|c|c|c|c|}
\hline Mean & SD & $\alpha$ & 1 & 2 & 3 \\
\hline Affective commitment (OC) & 3.97 & .90 & .76 & - & - \\
\hline Continuance commitment (OC) & 3.69 & 1.2 & .84 & - & - \\
\hline Normative commitment (OC) & 3.78 & 1.01 & .70 & - & - \\
\hline Job characteristics (RF) & 4.53 & 1.06 & .67 & $.19^{* *+}$ & $\mathrm{n} / \mathrm{s}$ \\
\hline Opportunities for training and development (RF) & 3.47 & 1.30 & .88 & $.40 * * *++$ & $\mathrm{n} / \mathrm{s}$ \\
\hline Supervisor support (RF) & 4.23 & 1.17 & .83 & $.22 * * *+$ & $\mathrm{n} / \mathrm{s}$ \\
\hline Career opportunities (RF) & 3.59 & 1.00 & .73 & $.46 * * *++$ & $.13 *+$ \\
\hline Work or life balance (RF) & 3.95 & 1.41 & .88 & $\mathrm{n} / \mathrm{s}$ & $\mathrm{n} / \mathrm{s}$ \\
\hline Commitment to organisation (RF) & 4.38 & 1.43 & .89 & $.61^{* * *+++}$ & $.34 * * *++$ \\
\hline
\end{tabular}

Commitment to organisation (RF)

$\mathrm{SD}$, standard deviation; $\alpha$, Cronbach's Alpha coefficients; OC, organisational commitment; RF, retention factors.
,$+++ r \geq .50$ (large practical effect size);,$++ r \geq .30-.49$ (medium practical effect size);,$+ r \leq .29$ (small practical effect size)

,$+++ r \geq .50$ (large practical effect size);,$++ r \geq .30$
$*, p \leq 0.05$ (two-tailed); $* *, p \leq 0.01 ; * * *, p \leq 0.001$

TABLE 2: Multiple regression analysis with retention factors as independent variables and organisational commitment as the dependent variable $(N=206)$.

\begin{tabular}{|c|c|c|c|c|c|c|c|c|c|c|c|}
\hline \multirow[t]{2}{*}{ Variables } & \multicolumn{2}{|c|}{$\begin{array}{l}\text { Unstandardised } \\
\text { coefficient }\end{array}$} & \multirow[t]{2}{*}{$\begin{array}{l}\text { Standardised } \\
\text { coefficient } \boldsymbol{\beta}\end{array}$} & \multirow[t]{2}{*}{$t$} & \multirow[t]{2}{*}{$p$} & \multirow[t]{2}{*}{$F$} & \multirow[t]{2}{*}{$d f$} & \multirow[t]{2}{*}{$\begin{array}{l}\text { Adjusted } \\
R^{2}\end{array}$} & \multirow[t]{2}{*}{$R$} & \multirow[t]{2}{*}{$\begin{array}{l}\text { Collinearity } \\
\text { statistics }\end{array}$} & \multirow[t]{2}{*}{$\begin{array}{l}\text { Tolerance } \\
\text { VIF }\end{array}$} \\
\hline & B & SE & & & & & & & & & \\
\hline Affective commitment (constant) & 1.49 & .25 & - & 5.94 & $.000 * * *$ & 45.9 & $3 ; 202$ & $.40+++$ & .64 & - & - \\
\hline Career opportunities & .18 & .06 & .20 & 3.28 & $.001^{* * *}$ & - & - & - & - & .76 & 1.31 \\
\hline Job characteristics & .14 & .05 & .17 & 2.96 & $.003 * *$ & - & - & - & - & .89 & 1.13 \\
\hline Normative commitment (constant) & 3.10 & .28 & - & 11.29 & $.000 * * *$ & 15.9 & $2 ; 202$ & $.12+$ & .36 & - & - \\
\hline Commitment to organisation & .28 & .05 & .40 & 5.64 & $.000 * * *$ & - & - & - & - & .86 & 1.16 \\
\hline Supervisor support & -.13 & .06 & -.16 & -2.19 & $.03^{*}$ & - & - & - & - & .86 & 1.16 \\
\hline Continuance commitment (constant) & 1.03 & .24 & - & 4.29 & $.000 * * *$ & 71.9 & $2 ; 202$ & $.41+++$ & .65 & - & - \\
\hline Commitment to organisation & .39 & .04 & .50 & 8.14 & $.000 * * *$ & - & - & - & - & .76 & 1.31 \\
\hline Career opportunities & .25 & .06 & .23 & 3.73 & $.000 * * *$ & - & - & - & - & .76 & 1.31 \\
\hline
\end{tabular}

$\mathrm{SE}$, standard error; $\beta$, beta; $t, t$-test; $p$, probability value; $F$, frequency; $d f$, degree of freedom; $R^{2}$, coefficient of determination; $R$, correlation coefficient; $\mathrm{VIF}$, variance inflation factor.

,$+ R^{2} \leq .12$ (small practical effect size);,$+++ R^{2} \geq .26$ (large practical effect size).

$*, p \leq .05 ; * *, p \leq .01 ; * * *, p \leq .001$

TABLE 3: Independent samples $t$-test - significant mean differences (gender).

\begin{tabular}{|c|c|c|c|c|c|c|c|}
\hline Variable & Gender & $N$ & Mean & SD & $p$ (two-tailed) & Cohen's $d$ & $\begin{array}{l}\text { Partial Eta } \\
\text { squared } \eta^{2}\end{array}$ \\
\hline \multirow[t]{2}{*}{ Affective commitment (OC) } & Men & 56 & 4.18 & .83 & $.04^{*}$ & .28 & .24 \\
\hline & Women & 150 & 3.90 & .91 & - & - & - \\
\hline \multirow[t]{2}{*}{ Career opportunities (RF) } & Men & 56 & 3.91 & 1.00 & $.00 * *$ & .39 & .39 \\
\hline & Women & 150 & 3.48 & .98 & - & - & - \\
\hline
\end{tabular}

$N$, used as means of numbers; $\mathrm{SD}$, standard deviation; $p$, probability value; $\mathrm{OC}$, organisational commitment; $\mathrm{RF}$, retention factors.

${ }^{*}, p \leq .05 ;{ }^{* *}, p \leq .01$ 


\section{Significant mean differences: Age}

Table 4 gives the ANOVA results. They provide some support that age groups differ significantly in their levels of satisfaction with retention factors and their organisational commitment. Table 4 shows that the participants in the 30-39 age group scored significantly higher than did the participants in the other age groups on job characteristics. The participants in the 17-29 age group years scored significantly lower on the job characteristics variable than the older age groups did. The size of these differences is moderate $\left(d \leq .66 ; \eta^{2} \leq 45 \%\right)$. The researchers observed no significant mean differences on the other RFS and OCQ variables.

\section{Significant mean differences: Race}

Table 5 gives the ANOVA results. They provide some support that race groups differ significantly in their levels of satisfaction with retention factors and their organisational commitment. Table 5 shows that the African participants scored significantly lower than the other race groups did on the compensation variable $\left(d=.64 ; \eta^{2}=76 \%\right.$; moderate in size). In terms of the participants' satisfaction with their job characteristics, the Asian $(\mathrm{M}=4.78)$ and White $(\mathrm{M}=4.66)$ participants scored significantly higher than the Coloured and African participants did $\left(d=.51 ; \eta^{2}=39 \%\right.$; small in size). The White $(\mathrm{M}=3.58)$ participants scored significantly lower on the work-life balance variable than did the African $(\mathrm{M}=4.61)$, Coloured $(\mathrm{M}=4.39)$ and Asian $(\mathrm{M}=4.11)$ participants $\left(d=.64 ; \eta^{2}=96 \% ;\right.$ moderate in size). The researchers observed no significant mean differences on the other RFS and OCQ variables.

\section{Significant mean differences: Tenure}

Table 6 gives the ANOVA results. They provide some support that tenure groups differ significantly in their levels of satisfaction with retention factors and their organisational commitment. Table 6 shows that the participants, who had worked for the organisation for longer than 11 years, obtained significantly higher scores on the affective commitment, normative commitment, compensation, job characteristics and commitment to organisation variables $(d \geq .26 \leq .70$; $\eta^{2}=5 \%-7 \%$; small to moderate in size). The researchers observed no significant mean differences on the other RFS and OCQ variables.

\section{Discussion}

This study adds to the empirical research that Döckel (2003) and Döckel et al. (2006) conducted in the South African context. Their research revealed that staff satisfaction with retention factors has a significant relationship with their organisational commitment.

The present study examined the relationship between the retention factors that Döckel (2003) identified and the threecomponent model of commitment of Meyer and Allen (1991) in a South African medical and information technology services company and how various biographical groups differed in terms of these constructs.
The present study showed that the participants' intention to stay with or leave their current company (commitment to the organisation) was a highly significant predictor of their affective commitment, continuance commitment and normative commitment.

The results are in agreement with the findings of Döckel et al. (2006). They showed that career opportunities predicted the participants' affective commitment and continuance commitment significantly. The findings also corroborate research that Joāo (2010) conducted. Joāo (2010) found that employees, who felt positive about the possibility of career advancement opportunities in their organisations and those who experienced intrinsic job satisfaction were more likely to feel emotionally attached to their organisations.

The results of the present study suggest that attending to human resource practices that increase the participants' overall satisfaction with the intra-organisational career opportunities that are available to them and the nature of their tasks may help to increase their psychological attachment to the organisation (affective commitment). Kondratuk, Hausdorf, Korabik and Rosin (2004) suggest that affective commitment increases after a move within or between organisations.

A lack of growth opportunities influences employees' attitudes to their organisations negatively. This, in turn, influences their intentions to leave and leads to turnover behaviour (Allen et al., 2003). Vallabh and Donald (2001) also found that career mobility is a leading factor in decisions to stay with or leave organisations.

The current study showed that job characteristics also positively predict the participants' affective commitment. This contradicts the findings of Döckel et al. (2006). According to Spector (2000), affective commitment occurs because of job conditions and the expectations that organisations meet. Continuance commitment occurs because of the benefits employees accumulate by working for their organisations and because there are no alternative jobs.

The current study showed that supervisor support negatively predicts participants' normative commitment. This also contradicts the findings of Döckel et al. (2006). The findings suggest that, the higher the participants' sense of moral obligation to remain with their organisation because of social norms (Meyer \& Allen, 1991), the lower is the influence of supervisor support as a retention factor. Döckel et al. (2006) and Lumley (2009) found that supervisor support relates more strongly to affective commitment. Supervisor support seems to relate to jobs and the cultures of organisations because it allows employees to make a difference, try out new skills, exercise discretion and receive feedback about their performance (Kochanski \& Ledford, 2001).

It is interesting to note that, contrary to the findings of Döckel et al. (2006), the participants' satisfaction with their work-life balance did not relate significantly to their organisational 
TABLE 4: Analysis of variance - significant mean differences between age groups.

\begin{tabular}{|c|c|c|c|c|c|c|c|c|c|}
\hline Variable & Age group & $N$ & Mean & SD & $\boldsymbol{F}$ & $d f$ & $p$ (two-tailed) & Cohen's $d$ & $\begin{array}{l}\text { Partial Eta } \\
\text { squared } \eta^{2}\end{array}$ \\
\hline \multirow[t]{4}{*}{ Job characteristics (RF) } & $17-29$ & 56 & 3.96 & 1.21 & 3.04 & 4 & $.03 *$ & .66 & .45 \\
\hline & $30-39$ & 150 & 4.76 & .94 & - & - & - & - & - \\
\hline & $40-49$ & 56 & 4.57 & 1.08 & - & - & - & - & - \\
\hline & Older than 50 & 150 & 4.51 & 1.12 & - & - & - & - & - \\
\hline
\end{tabular}

$N$, used as means of numbers; SD, standard deviation; $F$, frequency; $d f$, degree of freedom; $p$, probability value; RF, retention factors.

$*, p \leq .05$

TABLE 5: Analyses of variance - significant differences between race groups.

\begin{tabular}{|c|c|c|c|c|c|c|c|c|c|}
\hline Variable & Race groups & $N$ & Mean & SD & $F$ & $d f$ & $p$ (two-tailed) & Cohen's $d$ & $\begin{array}{l}\text { Partial Eta } \\
\text { squared } \eta^{2}\end{array}$ \\
\hline \multirow[t]{4}{*}{ Compensation (RF) } & White & 109 & 3.81 & 1.16 & 4.86 & 202 & $.00^{* *}$ & .63 & .76 \\
\hline & African & 27 & 3.08 & 1.13 & - & - & - & . & - \\
\hline & Coloured & 46 & 3.35 & 1.17 & - & - & - & & - \\
\hline & Asian & 24 & 3.13 & 1.12 & - & - & - & & - \\
\hline \multirow[t]{4}{*}{ Job characteristics (RF) } & White & 109 & 4.66 & 1.07 & 2.84 & 202 & $.03 *$ & .51 & .39 \\
\hline & African & 27 & 4.23 & 1.16 & - & & & & \\
\hline & Coloured & 46 & 4.24 & 1.08 & & & & & \\
\hline & Asian & 24 & 4.78 & .74 & & & & & \\
\hline \multirow[t]{4}{*}{ Work-life balance (RF) } & White & 109 & 3.58 & 1.45 & 6.60 & 202 & $.000 * * *$ & .63 & .96 \\
\hline & African & 27 & 4.61 & 1.16 & & & & & \\
\hline & Coloured & 46 & 4.39 & 1.07 & & & & & \\
\hline & Asian & 24 & 4.11 & 1.54 & & & & & \\
\hline
\end{tabular}

$N$, used as means of numbers; $\mathrm{SD}$, standard deviation; $F$, frequency; $d f$, degree of freedom; $p$, probability value; RF, retention factors.

$*, p \leq .05 ; * *, p \leq .01 ; * * *, p \leq .001$

TABLE 6: Analyses of variance - significant mean differences between tenure groups.

\begin{tabular}{|c|c|c|c|c|c|c|c|c|c|}
\hline Variable & Tenure & $N$ & Mean & SD & $F$ & $d f$ & $p$ (two-tailed) & Cohen's $d$ & $\begin{array}{l}\text { Partial Eta } \\
\text { squared } \eta^{2}\end{array}$ \\
\hline \multirow[t]{4}{*}{ Affective commitment (OC) } & Fewer than five years & 93 & 3.76 & .92 & 4.67 & 204 & $.00 * *$ & .65 & .06 \\
\hline & $6-10$ years & 47 & 3.97 & .82 & & & & & \\
\hline & $11-15$ years & 44 & 4.25 & .84 & & & & & \\
\hline & More than 15 years & 22 & 4.36 & .84 & & & & & \\
\hline \multirow[t]{4}{*}{ Normative commitment (OC) } & Fewer than five years & 93 & 3.62 & 1.06 & 3.74 & 204 & $.01^{*}$ & .58 & .05 \\
\hline & $6-10$ years & 47 & 3.65 & .91 & & & & & \\
\hline & $11-15$ years & 44 & 4.08 & .93 & & & & & \\
\hline & More than 15 years & 22 & 4.20 & .97 & & & & & \\
\hline \multirow[t]{4}{*}{ Compensation (RF) } & Fewer than five years & 93 & 3.34 & 1.19 & 2.85 & 202 & $.03 *$ & .70 & .04 \\
\hline & $6-10$ years & 47 & 3.55 & 1.08 & & & & & \\
\hline & $11-15$ years & 44 & 3.60 & 1.24 & & & & & \\
\hline & More than 15 years & 22 & 4.14 & 1.09 & & & & & \\
\hline \multirow[t]{3}{*}{ Job characteristics (RF) } & Fewer than five years & 93 & 4.32 & 1.12 & 3.44 & 204 & $.01 *$ & .26 & .04 \\
\hline & $11-15$ years & 44 & 4.93 & .91 & & & & & \\
\hline & More than 15 years & 22 & 4.60 & 1.17 & & & & & \\
\hline \multirow{4}{*}{$\begin{array}{l}\text { Commitment to } \\
\text { organisation (RF) }\end{array}$} & Fewer than five years & 93 & 4.14 & 1.58 & 5.28 & 204 & $.00 * *$ & .61 & .07 \\
\hline & $6-10$ years & 47 & 4.09 & 1.36 & & & & & \\
\hline & $11-15$ years & 44 & 5.01 & .94 & & & & & \\
\hline & More than 15 years & 22 & 4.80 & 1.26 & & & & & \\
\hline
\end{tabular}

$N$, used as means of numbers; SD, standard deviation; $F$, frequency; $d f$, degree of freedom; $p$, probability value; OC, organisational commitment; RF, retention factors. $*, p \leq .05 ; * *, p \leq .01$

commitment. This is an interesting finding because most of the sample comprised women and married participants.

The findings seem to corroborate research that Kniveton (2004) conducted. It showed that, although women have a high awareness of, and concern for, their family responsibilities, they see them as things they have to cope with, rather than as things that influence their perceptions of their careers. This suggests that, although companies should be aware of women's family concerns and responsibilities and their need for stability, benefit packages and flexible work arrangements (Coetzee \& Schreuder, 2008), organisations should take care not to let traditional gender stereotyping influence employees' need for career development opportunities.

With regard to the differences between biographical groups, the results showed that these differences were, in practical terms, small to moderate in size. One can attribute the 
higher levels of affective commitment and satisfaction with perceived career opportunities, which the men participants indicated, to the belief that most workplaces do not recognise women's needs for career advancement and emotionally supportive work environments (Martins \& Coetzee, 2007). Nabi (2001) also found that women have greater needs for emotionally supportive work environments as sources of career satisfaction. The research findings of Kidd and Smewing (2001) suggest a positive linear relationship between supervisor support and commitment, particularly for women.

With regard to age, the participants in the entry and establishment phases of their lives and careers seemed to be the least satisfied with the nature of their jobs and work tasks. Research by Coetzee and Schreuder (2008) suggests that employees in the early adulthood phase of their lives tend to prefer work situations in which they will be, as far as possible, free of organisational constraints and restrictions and free to develop their professional competence. They also tend to be active learners who require ongoing training and further development opportunities through on-the-job experiences that enable them to sharpen their talents and skills (making it possible for them to influence and lead others in service-orientated work environments).

With regard to race groups, the African and Coloured participants seemed to be the least satisfied with their compensation and the nature of their job and work tasks. These findings agree with the research of Martins and Coetzee (2007), who found that Black employees were more dissatisfied with their compensation. Research shows that compensation is a significant factor for retaining employees (Döckel et al., 2006; Joāo, 2010; Lumley, 2009).

Research data that Keaveny and Inderrieden (2000) reported suggest that when jobs are more interesting, provide greater job security and better benefits and opportunities for advancement than elsewhere, their employees are more satisfied with a given level of compensation. These findings are especially important in the light of the current employment equity and affirmative action policies in South African workplaces that strive to attract, develop and retain Black employees and women with scarce skills.

With regard to work-life balance, the White participants seemed to be the least satisfied with their work-life balance. Research by Coetzee et al. (2007) also found that Whites value work-life balance significantly more than their Black counterparts do. The researchers observed no significant differences between the organisational commitment levels of the various race groups. These findings are consistent with those of Coetzee et al. (2007), Ferreira and Coetzee (2010) and Lumley (2009).

With regard to tenure, the study showed that the participants with longer tenures ( 11 years and more) had significantly more emotional and normative attachments to the organisation.
These participants also seemed to feel significantly more satisfied with their compensation and jobs and indicated less intention to leave the organisation.

Meyer and Allen (1997) suggest that that one can expect employees' commitment to change over a period and then stabilise with tenure. Research by Meyer and Allen (1984) shows that older workers become more attitudinally committed to their organisations for a variety of reasons. These include greater satisfaction with their jobs, being in better positions and having 'cognitively justified' their continuance in their organisations.

The findings also seem to corroborate the research of Ferreira and Coetzee (2010). They found that older employees were affectively and normatively more committed to their organisations than their younger counterparts were. These employees are in the maintenance stage of their careers and may have come to appreciate their continued membership of their respective organisations.

\section{Implications for managers and recommendations}

The present study suggests that employees' satisfaction with retention factors has a significant relationship with their organisational commitment. The retention factors the researchers measured are all associated with human resource management practices that influence employees' intentions to leave (Döckel, 2003). Therefore, the associations the researchers observed between these constructs are important for managers who are interested in retaining the staff they have identified as having scarce skills.

The research of Kochanski and Ledford (2001) showed that skills shortages, and a high demand for employees, result in greater opportunities for career mobility. In addition, managers need to note the differences the researchers found between the gender, age, race and tenure groups on some of the retention factors and organisational commitment constructs. Although these differences ranged between practically small and moderate in size, the results give useful pointers for retaining diverse groups of employees in the South African multicultural work environment.

With regard to specific human resource practices, job motivation, career opportunities and supervisor support were important to all biographical groups (Bensin \& Brown, 2011). These findings suggest that managers need to ensure that all supervisors are well trained and support their workers as well as that all employees have career opportunities.

Encouraging career development benefits organisations because it facilitates appreciative learning climates and leads to greater productivity in the workplace (Govaerts et al., 2011; Naris \& Ukpere, 2010). Govaerts et al. (2011) found that employees who experience appreciative learning climates in their organisations are more inclined to stay. According to Rodriguez (2008), employees begin to search for external 
job opportunities once they feel they are no longer growing. Echols (2007) also argues that, when organisations combine learning and development with selective promotion and salary decisions, the process can be a strong retention factor.

\section{Possible limitations of the study}

Despite the strengths of this study and the new knowledge and insights it brings to the field of retention and human resource management, there are aspects that may limit it.

The researchers limited the present study to a sample of predominantly White and women participants who worked in a South African medical and information technology services company. Therefore, one cannot generalise the findings to other occupational, race, gender and industry groups.

Furthermore, given the exploratory nature of the research design, this study can yield no statements about causation. Therefore, the researchers inferred rather than established the associations between the variables.

\section{Suggestions for future research}

Researchers need to replicate these findings with broader samples in various occupational, age, race and gender groups as well as economic sectors before one can draw conclusions about the relationship between employees' levels of satisfaction with organisations' retention factors and their commitment to their organisations.

Based on the promising findings of this study, future empirical investigations that relate to retaining scarce and critical skills in the multicultural work context should attempt to corroborate the findings of the present study through longitudinal studies with other measures of retention factors and organisational commitment.

\section{Conclusion}

The study contributes valuable new and unique knowledge to the human resources field and practices concerned with retaining diverse groups of staff in the medical and information technology services sector.

The present study emphasises the importance of considering the retention factors the study highlights and how they influence employees' commitment to their organisations. Its results emphasise the importance of adopting a pluralistic approach to retention and career development practices to meet employees' diverse needs in a multicultural society (Coetzee \& Schreuder, 2008). This approach will also help organisations to retain diverse abilities in their workforces.

\section{Acknowledgements Competing interests}

The authors declare that they have no financial or personal relationship(s) that may have inappropriately influenced them when they wrote this paper.

\section{Authors' contributions}

J.v.D. (University of South Africa) conducted the research and statistical analyses and assisted with writing the report. M.C. (University of South Africa) supervised the research project and assisted with the statistical analysis and writing the report.

\section{References}

Allen, D.G., Shore, L.M., \& Griffeth, R.W. (2003). The role of perceived organizational support and supportive human resource practices in the turnover process. Journal of Management, 29, 99-118. http://dx.doi.org/10.1177/014920630302900107

Becker, H.S. (1960). Notes on the concept of commitment. American Journal of Sociology, 66(1), 32-42. http://dx.doi.org/10.1086/222820

Benson, J., \& Brown, M. (2011). Generations at work: Are there differences and do they matter? The International Journal of Human Resource Management, 22(9), 1843-1865.

Bentein, K., Vandenberghe, C., Vandenberg, R., \& Stinglhamber, F. (2005). The role of change in the relationship between commitment and turnover: A latent growth
modelling approach. Journal of Applied Psychology, $90(3), 468-482$. http://dx.doi. modelling approach. Journal of Applied Psychology,
org/10.1037/0021-9010.90.3.468, PMid:15910143

Bezuidenhout, M.M., Joubert, G., Hiemstra, L.A., \& Struwig, M.C. (2009). Reasons for doctor migration from South Africa. SA Family Practice, 51(3), 211-215.

Bhorat, H., Meyer, J.B., \& Mlatsheni, C. (2002). Skilled labour migration from developing countries: Study on South and Southern Africa. International Migration Papers (52), International Labour Office, Geneva. Retrieved August 10, 2011, from http://www.ilo.org/public/english/protection/migrant/download/imp/imp52e. pdf

Cohen, J. (1992). Quantitative methods in psychology: a power primer. Psychologica Bulletin, 112(1), 153-159.

Coetzee, M., \& Roythorne-Jacobs, H. (2007). Career counselling and guidance in the workplace: A manual for career practitioners. Cape Town: Juta.

Coetzee, M., \& Schreuder, D. (2008). A multi-cultural investigation of students' career anchors at a South African higher education institution. SA Journal of Labour Relations, 32(2), 1-11.

Coetzee, M., Schreuder, D., \& Tladinyane, R. (2007). Career anchors and its relation to organisational commitment. Southern African Business Review, 11(1), 65-86.

Döckel, A. (2003). The effect of retention factors on organisational commitment: An investigation of high technology employees. Unpublished master's thesis, University of Pretoria, Pretoria, South Africa.

Döckel, A., Basson, J.S., \& Coetzee, M. (2006). The effect of retention factors on organizational commitment: An investigation of high technology employees. SA Journal of Human Resource Management/SA TydskrifvirMenslikehulpbronbestuur, $4(2), 20-28$

Echols, M.E. (2007). Learning's role in talent management. Chief Learning Officer, 6(10), 36-40.

Ferreira, N., \& Coetzee, M. (2010). Psychological career resources and organisational commitment: Exploring socio-demographic differences. South African Journal of Labour Relations, 34(2), 25-41.

Field, A. (2005). Discovering statistics using SPSS. London: Sage Publications.

Govaerts, N., Kyndt, E., Dochy, F., \& Baert, H. (2011). Influence of learning and working climate on the retention of talented employees. Journal of Workplace Learning, 23(1), 35-55.

Hill, K.S. (2011). Work satisfaction, intent to stay, desires of nurses, and financial knowledge among bedside and advanced practice nurses. The Journal of Nursing
Administration, 41(5), 211-217. http://dx.doi.org/10.1097/NNA.0b013e3182171b17, PMid:21519207

Holtom, B.C., \& O'Neill, B.S. (2004). Job embeddedness: A theoretical foundation for developing a comprehensive nurse retention plan. The Journal of Nursing Administration, 34(5), 216-227. http://dxdoi.org/10.1097/00005110Administration,

Joāo, T.F. (2010). The relationship between perceived career mobility, career mobility preference, job satisfaction and organisational commitment. Unpublished master's dissertation. University of South Africa, Pretoria, South Africa.

Katz, D., \& Kahn, R. (1978). The social pscyhology of organizations. (2nd ed.). New York: Wiley.

Keaveny, T.J., \& Inderrieden, E.J. (2000). Gender differences in pay satisfaction and pay expectations. Journal of Managerial Issues, 12(3), 363-380.

Kidd, J.M., \& Smewing, C. (2001). The role of the supervisor in career and organizational commitment. European Journal of Work and Organisational Psychology, 10(1), 25-40. http://dx.doi.org/10.1080/13594320042000016

Kniveton, B.H. (2004). Managerial career anchors in a changing business environment Journal of European Industrial Training, 28(7), 564-573. http://dx.doi. org/10.1108/03090590410549984

Kochanski, J., \& Ledford, G. (2001). 'How to keep me': Retaining technical professionals. Research Technology Management, 44(3), 31-38.

Kondratuk, T.B., Hausdorf, P.A., Korabik, K., \& Rosin, H.M. (2004). Linking career mobility with corporate loyalty: How does job change relate to organizational mobility with corporate loyalty: How does job change relate to organizational org/10.1016/j.jvb.2003.08.004 
Korunka, C., Hoonakker, P., \& Carayon, P. (2008). Quality of working life and turnover intention in information technology work. Human Factors and Ergonomics in Manufacturing, 18(4), 409-423. http://dx.doi.org/10.1002/hfm.20099

Kraak, A. (2008). The education-economy relationship in South Africa, 2001-2005. Human Resources Development Review. Cape Town: HSRC.

Kraimer, M.L., Seibert, S.E., Wayne, S.J., Liden, R.C., \& Bravo, J. (2011). Antecedents and outcomes of organizational support for development: The critical role of career opportunities. Journal of Applied Psychology, 96(3), 485-500. http:// dx.doi.org/10.1037/a0021452, PMid:21114356

Lai, G., Lin, N., \& Leung, S. (1998). Network resources, contact resources and status attainment. Social Networks, 20, 159-178. http://dx.doi.org/10.1016/S0378 8733(97)00012-9

Lumley, E.J. (2009). Exploring the relationship between career anchors, job satisfaction and organisational commitment. Unpublished master's dissertation. University of South Africa, Pretoria, South Africa.

Luna-Arocas, R., \& Camps, J. (2008). A model of high performance work practices and turnover intentions. Personnel Review, 37(1), 26-46. http://dx.doi. org/10.1108/00483480810839950

Manetje, O., \& Martins, N. (2009). The relationship between organisational culture and organisational commitment. Southern African Business Review, 13(1), 87111.

Martin, S.S. (2008). Relational and economic antecedents of organisational commitment. Personnel Review, 37(6), 589-608. http://dx.doi. org/10.1108/00483480810906856

Martins, N., \& Coetzee, M. (2007). Organisational culture, employee satisfaction, perceived leader emotional competency and personality type: An exploratory study of a South African engineering company. SA Journal for Human Resource Management/SA Tydskrif vir Menslikehulpbronbestuur, 5(2), 20-32.

Maume, D.J. (1999). Occupational segregation and the career mobility of white men and women. Social Forces, 77, 1433-1459. http://dx.doi.org/10.1093/ sf/77.4.1433

Maurer, T.J., \& Lippstreu, M. (2008).Who will be committed to an organization that provides support for employee development? Journal of Management Development, 27, 328-347.

McKnight, D.H., Phillips, B., \& Hardgrave, B.C. (2009). Which reduces IT turnover intention the most: Workplace characteristics or job characteristics? Informatio \& Management, 46(3), 167-174. http://dx.doi.org/10.1016/j.im.2009.01.002

Metcalfe, B., \& Dick, G. (2002). Is the force still with her? Gender and commitment in the police. Women in Management Review, 17(7/8), 392-403. http://dx.doi. org/10.1108/09649420210451823

Meyer, J.P., \& Allen, N.J. (1984). Testing the 'side bet theory' of organisational commitment: Some methodological considerations. Journal of Applied Psychology, 69, 372-378. http://dx.doi.org/10.1037/0021-9010.69.3.372

Meyer, J.P., \& Allen, N.J. (1991). A three-component conceptualization of organizational commitment. Human Resource Management Review, 1(1), 61-89. http://dx.doi. org/10.1016/1053-4822(91)90011-Z

Meyer, J.P., \& Allen, N.J. (1997). Commitment in the workplace: Theory, research and application. London: Sage Publications.

Meyer, J.P., Allen, N.J., \& Smith, C.A. (1993). Commitment to organisations and occupations: Extension and test of a three-component conceptualization. Journal of Applied Psychology, 78(4), 538-551. http://dx.doi.org/10.1037/0021 9010.78.4.538

Morrow, P.C. (2011). Managing organizational commitment: Insights from longitudinal research. Journal of Vocational Behavior, 79, 18-35. http://dx.doi.org/10.1016/j. jvb.2010.12.008

Nabi, G.R. (2001). The relationship between HRM, social support and subjective career success among men and women. International Journal of Manpower, 22(5), 457-471. http://dx.doi.org/10.1108/EUM0000000005850
Naris, N.S., \& Ukpere, I.W. (2010). Developing a retention strategy for qualified staff at the polytechnic of Namibia. African Journal of Business Management, 4(6), 1078-1084.

Neininger, A., Lehmann-Willenbrock, N., Kauffeld, S., \& Henschel, A. (2010). Effects of team and organizational commitment: A longitudinal study. Journal of Vocationa Behavior, 76, 567-579. http://dx.doi.org/10.1016/j.jvb.2010.01.009

Netswera, F.G., Rankhumise, E.M., \& Mavundla, T.R. (2005). Employee retention factors for South African higher education institutions: A case study. SA Journa of Human Resource Management/SA Tydskrif vir Menslikehulpbronbestuur, 3(2), 36-40.

Ng, T.W.H., \& Feldman, D.C. (2009). Occupational embeddedness and job performance. Journal of Organizational Behavior, 30, 863-891. http://dx.doi.org/10.1002/ job.580

Ohlott, P.J., Ruderman, M.N., \& McCauley, C.D. (1994). Gender differences in managers' developmental job experiences. Journal of Applied Psychology, 77, 272-279.

Parkes, L.P., \& Langford, P.H. (2008). Work-life balance or work-life alignment? A test of the importance of work-life balance for employee engagement and intention to stay in organisations. Journal of Management and Organization, 14(3), 267-284. stay in organisations. Journal of Management
$\mathrm{http}: / / \mathrm{dx}$.doi.org/10.5172/jmo.837.14.3.267

Posthuma, R.A., \& Campion, M.A. (2009). Age stereotypes in the workplace: Common stereotypes, moderators, and future research directions. Journal of Management, 35, 158-188. http://dx.doi.org/10.1177/0149206308318617

Rasool, F., \& Botha, C.J. (2011). The nature, extent and effect of skills shortages on skills migration in South Africa. SA Journal of Human Resource Management/SA Tydskrif vir Menslikehulpbronbestuur, 9(1), Art. \#287, 12 pages. http://dx.doi. org/10.4102/sajhrm.v9i1.287

Reed, S.A., Kratchman, S.H., \& Strawser, R.H. (1994). Job satisfaction, organizational commitment, and turnover intentions of United States accountants: the impact of locus of control and gender. Accounting, Auditing \& Accountability Journal, $7(1)$ 31-58. http://dx.doi.org/10.1108/09513579410050371

Rodriguez. (2008). Learning's impact on talent flow. Chief Learning Officer, 7(4), 5064.

Savickas, M.L., Nota, L., Rossier, J., Dauwalder, J., Duarte, M.E., Guichard, J. et al (2009). Life designing: A paradigm for career construction in the 21st century.
Journal of Vocational Behavior, 75, 239-250. http://dx.doi.org/10.1016/j. Journal of Vocatic
jvb.2009.04.004

Shaughnessy, J.J., Zechmeister, E.B., \& Zechmeister, J.S. (2003). Research methods in psychology. (6th edn.). New York: McGraw-Hill.

Spector, P.E. (2000). Industrial \& organizational psychology: Research and practice. (10th edn.). New York: Wiley \& Sons.

Spector, P.E. (2008). Industrial and organisational psychology behaviour. (5th edn.). New Jersey: John Wiley \& Sons.

Statistical Package for the Social Sciences (SPSS). (2008). Statistical Programs for Social Sciences (SPSS): Version 17.0. SPSS Inc.

Statistics South Africa. (2005). Documented migration. Retrieved March 25, 2008, from http://www.statssa.gov.za.

Stroth, C. (2010). Job embeddedness as a nurse retention strategy for rural hospitals. Journal of Nursing Administration, 40(1), 32-35. http://dx.doi.org/10.1097/ NNA.0b013e3181c47d30, PMid:20010375

Vallabh, M., \& Donald, F. (2001). A comparison of black and white managers on intent to leave and job mobility. Journal of Industrial Psychology, 27(2), 37-42.

Van Dyk, J. (2011). The relationship between organisational commitment, retention factors and perceived job embeddedness. Unpublished master's thesis. University of South Africa, Pretoria, South Africa.

Weng, Q., McElroy, J.C., Morrow, P.C., \& Liu, R. (2010). The relationship between career growth and organizational commitment. Journal of Vocational Behavior 77, 391-400. http://dx.doi.org/10.1016/j.jvb.2010.05.003 